E N T R E V I S T A

\title{
ENTREVISTA COM HELOÍSA STARLING
}

\author{
Interview with Heloísa Starling \\ Entrevista con Heloísa Starling
}

\author{
CONCEDIDA A BERNARDO BUARQUE DE \\ HOLLANDA E MARCELINO RODRIGUES DA SILVA
}

Belo Horizonte, 22 de fevereiro de 2017

http://dx.doi.org/10.1590/\$2178-14942017000300013

Bernardo Borges Buarque de Hollanda é professor da Escola de Ciências Sociais da Fundação Getulio Vargas (CPDOC/FGV) (bernardo.hollanda@fgv.br). Marcelino Rodrigues da Silva é professor da Faculdade de Letras da Universidade Federal de Minas Gerais (UFMG), Belo Horizonte (lino-rodrigues@uol.com.br). 
om formação em História e Ciência Política, Heloísa Starling, professora titular livre de História do Brasil da Universidade Federal de Minas Gerais (UFMG), sempre cultivou em sua trajetória universitária o diálogo com a literatura, a música e as artes brasileiras em geral. Após uma tese de doutoramento dedicada à obra-prima de João Guimarães Rosa Grande sertão: veredas, esse trabalho nas fronteiras com o campo artístico-cultural vem se tornando cada vez mais intenso e diversificado. Tal diversificação decorre de uma produção intelectual que vem de par com iniciativas acadêmicas e editoriais coletivas e inovadoras, adquirindo a marca de uma história pública em sentido pleno.

Fiel ao preceito de que a universidade tem por missão articular ensino, pesquisa e, sobretudo, extensão, Heloísa Starling vem desenvolvendo projetos, eventos e seminários capazes de atingir um público mais amplo. Não se trata simplesmente de estratégias de disseminação do conhecimento científico, mas do cultivo de uma interlocução com a sociedade em uma via de mão dupla: como se sabe, cabe à universidade extrapolar o insulamento de seus campi, criando vínculos externos com o restante da população, de modo a tornar suas atividades atraentes e relevantes não apenas para estudantes e professores.

Nesse sentido, pode ser mencionada a organização de seminários interinstitucionais como o "Decantando a República", realizado em 2001 na PUC-Rio, com a reunião de uma nata de intelectuais que se debruçou sobre a obra musical de nomes como Noel Rosa, Tom Jobim e Chico Buarque - para ficar apenas com alguns, de predileção da professora Heloísa -, a fim de delinear o "inventário histórico e político" da moderna canção popular brasileira. Pode também ser lembrado o seminário "Sentimentos do Mundo", comemorativo dos 80 anos de fundação da UFMG, em 2008, que teve a participação de destacadas referências literárias internacionais, como por exemplo o escritor moçambicano Mia Couto e a crítica argentina Beatriz Sarlo.

Esses eventos, entre outros, amplificaram-se graças à publicação de livros, CDs, DVDs e outros produtos de alta qualidade, utilizados com fins culturais e didáticos, muitos dos quais realizados em parceria com personalidades da cultura brasileira. Basta lembrar o memorável show de Maria Bethânia no campus da UFMG, em que a cantora declamou uma série de poemas da língua portuguesa, de Fernando Pessoa a João Cabral de Melo Neto, de Luís de Camões a Ascenso Ferreira, espetáculo que foi publicado sob a forma de um esmerado Caderno de poesia. 
Entre as iniciativas da professora, podemos ainda citar o Projeto República, um centro de memória e documentação voltado para a preservação da história republicana brasileira e para a reflexão sobre o alcance do republicanismo no país. De seus projetos de extensão mais recentes, vale ainda lembrar o "Sentimentos da Terra", um caminhão-museu itinerante que percorre as cidades brasileiras, interage com públicos locais e narra as diversas formas de luta pela terra no interior do país ao longo da história nacional, incluindo as reservas indígenas, as experiências quilombolas e os projetos de reforma agrária.

Nesta entrevista, concedida em Belo Horizonte no início de 2017, Heloísa Starling fala de sua trajetória biográfica e acadêmica, explicando os motivos que levaram uma jovem estudante mineira a optar pelos cursos de História e Jornalismo, em meados dos anos 1970, ainda em plena vigência do regime militar.

A entrevistada aborda também sua dissertação de mestrado, defendida no Departamento de Ciência Política da UFMG em meados dos anos 1980. Em um estudo denso, a autora apresenta os resultados de sua pesquisa sobre as origens da ditadura militar, amparada por fontes primárias então desconhecidas e ainda hoje pouco exploradas acerca da gênese, da conformação ideológica e do desfecho do golpe de 1964 no estado de Minas Gerais.

Heloísa trata do livro decorrente de sua dissertação - Os senhores das Gerais: os Novos Inconfidentes e o golpe de 1964 - e mostra sua interlocução com outros pesquisadores que, na conjuntura de fins da década de 1980, também publicavam trabalhos sobre a deposição de João Goulart, tais como Wanderley Guilherme dos Santos, autor de uma "anatomia de uma crise", e seu próprio orientador, René Dreifuss, que publicou naquela época o polêmico 1964: a conquista do Estado.

Starling discorre ainda sobre seu doutorado em Ciência Política no IUPERJ, concluído em 1997 sob a orientação do professor José Murilo de Carvalho. Nessa altura, relata como surgiu seu interesse pela Teoria Política e pela questão republicana, relativa à res publica, que se consolidaria como um dos grandes temas de sua carreira, analisando para tanto a influência da formação iuperjiana nesse processo.

0 doutoramento também marca sua aproximação com a literatura, pois é neste momento que ela se dedica a Grande sertão: veredas. 0 estudo da obra de João Guimarães Rosa enfrenta o desafio de lidar com a temática ficcional no interior das Ciências Sociais em uma instituição de referência da pós-graduação em Sociologia e Ciência Política no Brasil.

Ao contrário do que seria de se esperar entre historiadores, politólogos e cientistas sociais, a leitura de Starling do romance de Guimarães Rosa não se limita a esquematizações sociológicas ou a vieses externalistas/contextualizadores. Identifica-se sua opção por um corpo a corpo com a ficção, destrinchando o intrincado enredo roseano, o que é evidenciado por 
meio de inúmeras citações diretas e fragmentárias à obra, influência de teóricos caros à sua formação como Walter Benjamin.

Em consonância com a temática do presente dossiê, a entrevista detém-se na interface história/literatura e analisa suas implicações do ponto de vista da escrita da História, considerando o alcance e os limites da ficção na historiografia. Starling se posiciona diante de um debate que, como é sabido, parte do campo dos Estudos Literários, desde as revisões epistemológicas de Hayden White nos anos 1970 até os mais recentes ensaios filosóficos de Jacques Rancière, dedicados aos efeitos pragmáticos e políticos das práticas estéticas, configuradoras das formas de imaginar e construir a realidade.

Esse interesse da autora pela literatura e pelas artes se desdobra nos estudos da história da moderna canção popular no Brasil. Heloísa comenta como a música brasileira ganha vulto em sua agenda de pesquisas, convertendo-se em um de seus principais campos de investimento reflexivo. Avalia, assim, até que ponto o trabalho com o cancioneiro popular pode ser considerado um alargamento de seu método de análise da ficção literária, tal como empreendido na leitura de obras de Euclides da Cunha, Graciliano Ramos e Guimarães Rosa.

Por fim, Heloísa Starling trata de uma de suas últimas publicações, ao refletir sobre a ideia de uma "biografia" do Brasil, presente no título do livro escrito em parceria com a antropóloga Lilia Schwarcz. A metáfora biográfica do país é avaliada pela autora menos como uma reiteração da visada nacionalista, tão presente nos séculos XIX e XX, e mais como um diálogo com o potencial constitutivo da ficção e com o papel da imaginação no processo de reconstituição histórica.

\section{Heloísa, para começar, gostaríamos que nos falasse sobre o início de sua vida acadêmica.}

Em 1975, eu ingressei simultaneamente em Comunicação Social, na PUC de Minas Gerais, e em História, na UFMG. Analisando retrospectivamente, o que me atraía no Jornalismo era a escrita e o desejo de falar sobre o momento atual. Contudo, quando tive experiência na área, percebi que aquilo não funcionava tão bem para o que eu queria, porque eu recebia uma pauta e precisava seguir o que me mandavam fazer. Eu não via graça em escrever sobre certas coisas distantes dos meus interesses, e também não tinha disciplina para aquele sistema. Hoje, considero que se tivesse ido mais além, poderia ter sido importante para o desenvolvimento da minha escrita. Ainda assim, peguei um momento muito privilegiado da PUC, no qual tive aula de redação com o Sérgio Sant'Anna e de teatro com o Alcione Araújo. Lá havia muita criatividade para usar os diferentes suportes da linguagem, um aspecto experimental e uma abertura para as artes. Isso também me formou historiadora. 
História, por sua vez, me fornecia ferramentas bem legais. Porém no curso da UFMG existia algo ruim, que era a concentração de estudos sobre o Período Colonial. Hoje pode parecer bobo, mas havia uma grande discussão, e o resultado era que ninguém podia estudar períodos recentes. Eu me lembro de uma grande professora da época repetir que a História do Brasil acabava na Revolução de 1930. Dali em diante, era outra coisa. Portanto, o Jornalismo me fornecia acesso ao que a História negava. Por outro lado, tínhamos um deslumbramento em estarmos naquela faculdade e frequentarmos o Cineclube da Face - onde assisti a filmes importantes para a minha formação - e o Centro Cultural da UFMG. Circulavam no campus jornais como o Gol a gol se pegá com o pé é dibra e, naquele momento, a questão da cultura e da política estavam bastante ligadas.

Atualmente tenho um orientando querendo demonstrar em sua tese que na UFMG o movimento estudantil suportou o período mais bravo da ditadura militar por meio da cultura. Ali abri minha cabeça, aprendi sobre muitas coisas que não tinha vivido na adolescência e encontrei pessoas que pensavam de maneira parecida com a minha. Ao lado delas eu passava o dia todo na universidade, e vivíamos aquela coisa da felicidade pública expressa pelo Thomas Jefferson e pela Hannah Arendt, ou seja, experimentávamos, conhecíamos, discutíamos, ficávamos apaixonados, namorávamos...

Embora eu tenha uma grande proximidade com uma parte do Partido dos Trabalhadores, jamais fui filiada a um partido político oficial ou clandestino. Porém participei de uma tendência do movimento estudantil, chamada Liberdade e Luta, que foi muito importante na minha vida. A Libelu foi uma organização importante aqui em Belo Horizonte e na USP. Não entramos no Rio de Janeiro porque lá o Partidão era muito forte entre os estudantes. Já na UFMG, fazíamos um estrago. A Liberdade e Luta possuía um viés cultural muito grande e estimulava a leitura. Foi dentro dela que ouvi falar sobre Walter Benjamim, Albert Camus e outros pensadores com estigma de malditos que foram fundamentais na minha formação.

Portanto, vivi a segunda metade dos anos 1970 com essa grande vitalidade cultural na UFMG e uma forte experimentação na PUC. Tudo isso deixou marcas e orientou as minhas escolhas.

\section{Então sua participação no movimento estudantil não começou no seu tempo de secundarista?}

Não. Ela aflorou apenas na universidade. Na minha adolescência esse movimento jovem já não era tão forte quanto no final dos anos 1960, pois a repressão havia sido intensa. Eu sempre morei no bairro Santo Antônio, a dois quarteirões da velha FAFICH. Contudo, não tenho certeza se me recordo ou não do momento em que ela foi invadida por tropas militares, 
em 1968. Mais tarde, quando eu estava próxima de prestar o vestibular, assisti a algumas aulas lá, no antigo Coleginho, mas ainda não tinha uma relação próxima com o ambiente universitário ou com o movimento estudantil.

\section{Você disse que naquele momento o Departamento de História da UFMG estava muito associado ao estudo do Brasil Colonial. Como era isso?}

Era um verdadeiro horror para quem queria estudar o período republicano. Tudo era muito conservador. Entretanto, observando em retrospecto, percebo que aquela era uma fase de transição, em que professoras como Maria Efigênia Lage de Resende, Norma de Góes Monteiro e Beatriz Ricardina estavam começando a investir na pesquisa, e na qual docentes essenciais para o desenvolvimento do curso e para a criação da pós-graduação, como Eliana de Freitas Dutra e Carla Maria Junho Anastasia, ainda estavam terminando os seus cursos de mestrado e doutorado. Portanto, permanecia uma ênfase muito grande no período colonial. Isso me marcou, mas tempos depois acho que resolvi o meu problema em relação ao estudo dessa época. Atualmente estou fazendo um livro sobre o século XVIII e me encantei com tudo que andei aprendendo. Só resta agora eu me acertar quanto ao período imperial.

\section{Como começou sua trajetória de pesquisadora dentro dessa graduação que restringia os estudos sobre os períodos históricos mais recentes?}

Na verdade, ainda existia pouca pesquisa na UFMG, mas a Norma de Góes Monteiro produzia um dicionário sobre a história de Minas Gerais e me tornei bolsista para atuar nesse projeto. Acabei não durando 15 dias. Meu trabalho era ir ao Arquivo Público Mineiro, pesquisar jornais e apresentar um resultado. Eu lia os periódicos, achava fascinante a coluna social, os anúncios de filmes, porém não conseguia resultado algum. Eu era uma pesquisadora lamentável e fui demitida. Ainda assim, foi uma experiência significativa durante a graduação, porque me possibilitou um primeiro contato com os documentos.

Outra professora muito importante para que eu estabelecesse uma relação com as fontes históricas foi Maria Efigênia Lage de Resende. Na época, a grade do curso possuía quatro semestres de período colonial, dois ou três de Império e um de República. Ela lecionava Brasil Colônia e nos forçava a ler documentos, relatos de viajantes e vários autores. Dessa maneira, por mais marxista que eu fosse naquele momento e só quisesse ler Caio Prado Júnior, minha formação em História do Brasil é muito tributária dela. As provas eram orais e não tínhamos como escapar das leituras. Eu carrego culpas eternas por ter discutido, 
dizendo que não devíamos ler Sérgio Buarque de Holanda, hoje minha principal referência. Assim, tive um desenvolvimento que considero essencial, pois me forneceu ferramentas para o futuro.

\section{Nesse contexto, como nasceu seu interesse pela área de Ciência Política?}

Fui para essa área porque desejava estudar a contemporaneidade, e os professores da UFMG diziam que a História do Brasil terminava em 1930. Naquele momento, o programa de pós-graduação da USP não era o melhor lugar para estudar História das Ideias ou Brasil Contemporâneo. Até hoje, não é o forte de lá. A solução então foi ir para o Departamento de Ciência Política da UFMG, que passava por um momento bastante interessante, pois lecionavam lá o René Dreifuss, o Bernardo Sorj, o Antônio Mitre, o Fábio Wanderley Reis. E tinha a Carla Maria Junho Anastasia, que fez a sua pós no DCP, e era então uma jovem professora da História que teve grande influência na minha formação.

No DCP, os professores discutiam a ditadura militar, algo formidável! 0 Dreifuss estava terminando o 1964, a conquista do Estado: ação política, poder e golpe de classe, e eu queria muito perguntar a ele como o nosso país havia chegado àquele regime e como poderíamos enfrentá-lo. Fiz então um curso dele e soube que poderia existir em Minas Gerais uma perna do tema que ele estava trabalhando nacionalmente, no caso uma seção do Instituto de Pesquisas e Estudos Sociais. Consideramos que isso daria uma dissertação de mestrado. Ali, então, aprendi a fazer pesquisa, a procurar documentos, e esse estudo gerou o livro Os senhores das Gerais: os Novos Inconfidentes e o golpe de 1964, no qual sustento que Dreifuss tinha razão em sua tese, ou seja, de fato, os empresários e militares responsáveis pelo projeto de Brasil da ditadura militar tentaram coordenar os focos de conspiração. Para tanto, eles possuíam um eixo principal no Rio de Janeiro e em São Paulo e três pernas regionais: uma em Pernambuco, outra no Rio Grande do Sul e uma terceira em Minas Gerais.

\section{Havia uma efervescência política em Pernambuco naquela época, em razão da eleição do Miguel Arraes para o governo do estado, não é mesmo?}

Sim, os documentos do IPES nacional e do IPES de Minas Gerais mostram que eles despejaram uma grande quantidade de recursos lá por causa do Miguel Arraes, das Ligas Camponesas, da reforma agrária... Eles sabiam que precisavam atuar ali. É uma pena ninguém ainda ter estudado essa questão em relação a Pernambuco e, também, que o trabalho feito sobre o IPES do Rio Grande do Sul seja pouco divulgado. 
Outra coisa que me incomoda é como a historiografia sobre o golpe militar reagiu mal a essa discussão. Na época, o Dreifuss foi duramente combatido pela esquerda, que o acusava de querer livrar a cara dos militares. Hoje, eu entendo a questão da seguinte forma: os grupos políticos que repudiavam a ditadura queriam reconhecer uma origem democrática. Eles construíam uma simplificação narrativa sustentada na ideia de que nossas opções pela democracia tinham fundas e autênticas raízes históricas; portanto, os militares foram exceção. 0 que 0 Dreifuss dizia desmanchava essa narrativa: o golpe de 1964 foi o resultado de uma articulação entre empresários e militares com o objetivo de reorganizar o Estado, tinha natureza política civil e militar e só foi possível graças ao caráter amplo e heterogêneo da frente social que se reuniu para depor João Goulart.

Tudo isso gerou uma reação não necessariamente positiva ao trabalho dele, principalmente na universidade. Outro ponto interessante é que depois do Dreifuss ninguém avançou na discussão sobre a participação dos empresários na articulação do golpe. O IPES continuou até 1973 e toda a estrutura da ditadura, a partir de 1964, saiu de lá. Por que, então, paramos de estudar isso? Provavelmente, ali estão escondidos alguns dos melhores segredos da ditadura militar e os indícios para compreendermos a proeminência da participação dos empresários na sustentação daquele regime.

Infelizmente, alguns historiadores dizem: "Ah! O IPES não foi tão importante. Era apenas um centro de conspiração." Não era. Para provar a importância dele basta analisarmos quem esteve no governo dos militares e qual era a origem dessas pessoas; ou pensarmos em como foi construído o Serviço Nacional de Informações, que era a ponta da estrutura de repressão. 0 IPES teve papel decisivo em dois aspectos: o primeiro consistiu na preparação e execução de um bem orquestrado esforço de desestabilização do governo, que incluía custear uma campanha de propaganda anticomunista, bancar diversos tipos de manifestação pública antigovernista e escorar, inclusive financeiramente, grupos e associações de oposição ou de extrema direita. 0 segundo traçou estratégias de planejamento e de diretrizes para subsidiar um novo projeto de governo e de desenvolvimento para o país, aberto ao fluxo do capital internacional e com vocação profundamente autoritária. Então, talvez esse tema volte. Recentemente, um historiador [Pedro Henrique Pedreira Campos] fez um trabalho chamado Estranhas catedrais, no qual discute as relações das empreiteiras com a ditadura. Ele fez um livro muito bom, mas praticamente só existe esse trabalho e, convenhamos, ainda é pouco. Eu queria ver mais estudos sobre isso. A documentação é difícil, entretanto esse é um dos assuntos que a historiografia precisa olhar direito. 


\section{Os senhores das Gerais foi sua primeira pesquisa, que impressiona, entre outras coisas, pelo trabalho de fôlego para um mestrado e pelo fato de ter sido quase que imediatamente publicada. Isto em uma época em que era menos frequente a circulação e a publicação de trabalhos acadêmicos. A que você atribui esse êxito?}

Tudo isso aconteceu por três razões. Primeiramente, o Dreifuss foi um orientador extraordinário, porque já havia levantado uma enorme documentação nacional sobre o tema e sabia indicar onde eu poderia farejar. Além disso, ele colocava meus pés no chão. Em segundo lugar, eu tinha estratégias que aprendi no jornalismo. Por exemplo, em uma etapa da pesquisa eu estava certa de que existiu um organismo intermediário para o golpe aqui em Minas Gerais, porque não fazia sentido aqueles empresários se envolverem em ações tão imediatas. Pensei então que eles deveriam estar preocupados com o projeto ou com o que fazer com suas indústrias. Por isso, entrevistei uma porção deles e combinei com o Dreifuss que iria, como um jornalista, arriscar.

Então, certa ocasião indaguei a um deles: "Isso funcionou como um organismo intermediário que vocês criaram, não é?" Ele me olhou e questionou: "Mas como você descobriu os Novos Inconfidentes?" Pensei então: "Acabei de descobrir." [risos]. A partir dali, passei a indagar aos outros: "E os Novos Inconfidentes?" Eles achavam que eu sabia do que se tratava e contavam algo ou forneciam documentos. Essa estratégia, sem dúvida, foi de jornalista, não de historiador. Outro exemplo dessa técnica investigativa foi a que usei para conseguir mais informações sobre a Liga da Mulher Democrata. Nesse caso, fui ao cartório para saber a quem pertencia o prédio e usei o catálogo telefônico da época para ver no nome de quem estava. 0 historiador, hoje, talvez também faça isso, mas eu aprendi essas técnicas na Comunicação. Portanto, reuni esses dois campos para escrever Os senhores das Gerais.

Por fim, a publicação do meu trabalho se explica porque o livro do Dreifuss havia saído pela Editora Vozes e ele me ajudou, justificando aos editores que seria uma obra importante para ampliar o argumento e o raio de investigação sobre o golpe. E aconteceu isso mesmo. O Dreifuss tinha um plano naquele momento, que depois abandonou, de conseguir pesquisadores mais jovens que estudassem aquele assunto no âmbito regional. Outra aluna do DCP, também orientanda do Dreifuss, a Solange Simões, elaborou o primeiro trabalho sobre a participação das mulheres no golpe. Depois, uma orientanda do Carlos Fico também fez isso muito bem, mas pelo que sei não publicou o trabalho. Solange foi a primeira a estudar as participantes da Liga da Mulher Democrata. Infelizmente, o Dreifuss saiu de Minas Gerais, foi para o Rio de Janeiro e desistiu desse grande projeto. Se ele tivesse persistido, teríamos mais documentação para isso. Especulando, talvez ele tenha se aborrecido com a recepção 
extremista do trabalho dele na universidade: alguns o consideravam muito bom, mas em outros provocou enorme desconforto, especialmente no campo das esquerdas. Para muita gente parecia ser uma tentativa, até estimulada pelos próprios militares estigmatizados, de evitar serem considerados os únicos culpados pela ditadura.

\section{Você sentiu esse tipo de recepção em relação ao seu livro?}

Não. Os senhores das Gerais foi muito bem recebido. 0 máximo que ouvi foi o questionamento de alguns professores do DCP que me diziam: "Você não está apostando muito nessa ideia de conspiração?" Afora isso, não sofri a resistência meio oculta, meio explícita, como aquela aplicada ao Dreifuss. 0 meu livro saiu um pouco depois do dele e penso que tinha muito a ver com a História que nós, da esquerda, queríamos ver, ou seja, uma história que mostrasse como uma sociedade democrática foi miseravelmente reprimida. 0 Daniel Aarão Reis tem uma discussão muito boa sobre isso. Para alguns, no entanto, o trabalho do Dreifuss atrapalhava esse discurso.

\section{Após a conclusão do mestrado, você foi fazer o doutorado no IUPERJ, no Rio. Essa escolha teve uma razão específica?}

Eu fui para lá porque queria continuar o trabalho do Dreifuss e entender o que aconteceu com o IPES e com aqueles empresários após o golpe. Estudo que até hoje não foi feito. Apresentei o projeto e encontrei outro orientador emblemático na minha vida, que se tornou uma grande referência para mim - o José Murilo de Carvalho. Eu tive sorte, pois o momento do IUPERJ era muito bom. Lá descobri a Teoria Política e tive um extraordinário e deslumbrante professor, o Cesar Guimarães. Ele e o Sérgio Abranches, que me ensinou análise política e teoria contemporânea, abriram minha cabeça. Além disso, também havia o pessoal jovem, como o Newton Bignotto - que estava voltando do doutorado na França e é meu parceiro hoje na UFMG. No IUPERJ tinha também o Marcelo Jasmim, o Luiz Eduardo Soares e o Ricardo Benzaquen. Todos eles são muito bons, sabem tudo de teoria. 0 meu macete era ficar perto deles, só ouvindo...

Eu ingressei no doutorado com o intuito de prosseguir estudando o tema que havia desenvolvido no mestrado, porém no meio do caminho mudei de direção. Isso aconteceu em razão de um exame do IUPERJ, que fazia parte da qualificação e deixava todo mundo apavorado. Em determinado momento do curso eles sorteavam um determinado conceito, e os alunos tinham um mês para produzir um ensaio, perseguindo o conceito sorteado. No final, 
eles avaliavam e atribuíam uma nota. Era uma loucura, mas você saia daquilo com um conhecimento assentado. 0 meu ponto sorteado foi "fortuna e virtú". Fiz então um texto chamado "O problema de Alice: as noções de virtú e fortuna e seus desdobramentos na Teoria Política", todo montado em cima do livro clássico de Lewis Carroll, Alice no país das maravilhas. A banca, formada pelo Wanderley Guilherme dos Santos e pelo José Murilo de Carvalho, achou interessante o fato de eu lidar com literatura e também com a canção American pie. Em razão disso, o IUPERJ acabou publicando meu trabalho. Essa publicação acabou mudando toda a minha direção.

\section{Em Os senhores das Gerais já apareciam epígrafes com referências a trechos de música e de literatura brasileira. Já havia ali o indício de um interesse, não é?}

Sim. Eu já estava perseguindo o caminho de como transmitir a História para um público não acadêmico. Para tanto, usei letras de canções da Nara Leão e de outros compositores. Eu queria criar algo legal de se ler e que tivesse um contexto mais interessante, ligado à cultura.

\section{E como se deu a guinada que você citou ao longo do doutorado?}

Após a publicação de "O problema de Alice", o José Murilo de Carvalho me aconseIhou: "Seus estudos têm muito a ver com literatura, por que você não arrisca tudo?" Eu o questionei: "Como vou fazer isso?" Ele respondeu: "Você é de Minas! Guimarães Rosa!" [risos]. Fui ler o Grande sertão: veredas, e ele bancou com muito rigor a maluquice que era partir dessa obra para se pensar a Teoria Política. Nesse caso, não se tratava apenas de orientar, mas de gerir problemas técnicos que significaram um atraso na minha tese. Isso porque, em dado momento, ele me disse: "Literatura não é suporte da História ou da Política, mas é linguagem. Você vai ter que dar conta da literatura." Então, fui fazer cursos nas Letras, onde conheci o Wander Melo Miranda, uma pessoa importantíssima para me fazer pensar os caminhos da ficção. Quando estava frequentando um de seus cursos sobre memória, ele olhou para mim, que vinha da História, e resmungou: "Ah! Não vai dar! Eu não mereço isso!" Depois, frequentei aulas da Eneida Maria de Souza, que, embora tivesse ainda menos paciência comigo, foi essencial para me mostrar que a literatura tinha a sua própria linguagem e procedimentos e que não adiantava eu pensá-la como uma moldura da História.

Tudo isso atrasou a minha pesquisa e eu tive uma qualificação dificílima, porque cruzar literatura, História e Teoria Política no velho IUPERJ não foi fácil. O instituto era aberto, todavia 
tinha limites [risos]. O Wanderley Guilherme dos Santos e o Cesar Guimarães compuseram a minha banca e apresentaram questões bastante pertinentes. Foi barra pesada. Eu saí de lá rodando, a ponto de o José Murilo me levar para tomar um café. [risos]. Na ocasião, ele me acalmou: "Olhe, é assim mesmo. Eles estão certos, preste atenção, você precisa..." Eu estava achando que era a rainha da cocada preta porque tinha escrito "O problema de Alice" e todo mundo havia gostado. Levei uma surra muito bem dada. 0 fato de não terem aliviado foi essencial, porque me levou a refazer tudo.

\section{Qual era o sentido da crítica formulada pela banca? Era relativa à metodologia histórica ou ao objeto literário em si?}

Eles cobravam que eu mostrasse, de fato, que havia no romance uma interpretação do Brasil, uma reescrita crítica do país usando as ferramentas de várias tradições do pensamento político. E que havia em Grande sertão: veredas um paradigma da fundação política do Brasil. Eu precisava encontrar aquilo expresso claramente no texto. Eles tinham razão, pois argumentavam que eu não apresentava provas para sustentar a minha hipótese.

\section{Você já era leitora do Guimarães Rosa quando recebeu a sugestão do José Murilo de Carvalho?}

Não. Eu comecei naquele momento e me lembro de reclamar: "Esse cara é muito chato, José Murilo." Ele, calmo, insistia: "Passe as primeiras 50 páginas." Eu lia e retornava: "Continua chato." O José Murilo seguia extraordinariamente paciente, enquanto eu continuava resmungando, até que um de seus conselhos, de fato, funcionou. Ele disse: "Deixe. Pare de pensar. Não fique querendo entender tudo, pensando na tese, apenas leia." Dali em diante, entrei naquele universo e não saí mais.

Outra estratégia que o José Murilo usou foi mandar eu conhecer os livros que o Guimarães Rosa havia lido. Então, eu fui à biblioteca dele e encontrei um monte de livros esotéricos. Eu me recordo de dizer, espantada: "0 que é isso, gente?! Eu achando que esse homem era o grande pensador da República, mas ele só lia essas bobagens?!" O José Murilo, na ocasião, falou: "Não é possível. Isso não está resolvido e deve haver uma explicação."

Descobri na sequência que durante algum tempo Guimarães Rosa elaborava as provas para a seleção do Itamaraty e fui até lá buscar informações. Então, alguém me disse para eu procurar uma funcionária que havia sido secretária dele. Consegui encontrá-la e ela me explicou: "O João Rosa era pão-duro. Tudo que tinha na Biblioteca do Itamaraty, ele 
não comprava." Assim, entendi onde ele lia Teoria Política. Não precisou ler tudo, porque a ficção tem suas próprias antenas para capturar coisas no mundo. Todavia, ele tinha uma formação autodidata nessa área. Recentemente conheci o embaixador Alberto da Costa e Silva, contei esse caso, e ele me confirmou rindo: "Era isso. 0 Rosa era pão-duro mesmo." [risos]

Finalmente, depois da surra na qualificação, eu refiz várias vezes a tese até o José Murilo achar que estava boa. 0 trabalho era novo, pois o que existia era uma leitura do Guimarães Rosa com jagunços, datada historicamente. Eu estava dizendo que havia um projeto de Brasil, de fundação republicana, proposto em sua obra. Se hoje eu fosse reescrever o livro Lembranças do Brasil, fruto da tese, eu cruzaria muito melhor o tempo histórico em que o romance ocorre com os demais elementos. Era o ponto que o José Murilo queria que eu fizesse melhor - e acho que não dei conta de fazer como poderia. Contudo, naquele momento, a relação entre história e ficção ainda não era tão confortável para os historiadores. Eu me lembro da Isabel Lustosa - uma pioneira nessa discussão - e da Helena Bomeny sofrendo para construir bons argumentos lá no IUPERJ também. Nós queríamos dizer que existia uma conversa entre essas dimensões, porém a turma das Letras não aceitava, tampouco a da História e menos ainda a da Ciência Política.

\section{Em Lembranças do Brasil, você pensa o Grande sertão: veredas como um jogo que Guimarães Rosa elabora, criando uma ponte direta entre ficção e Teoria Política. Ou seja, você não fez uso do romance como um documento, a fim de tentar ver a História diretamente por meio dele, mas analisou a construção romanesca e o jogo literário que ele construiu, não é?}

Exatamente. 0 importante na experiência do Lembranças do Brasil era a ideia de que a ficção fala por si e fornece determinadas dimensões da realidade que a História não consegue alcançar sozinha. Quando pensamos em todas as alternativas possíveis contidas em um dado momento, e que não se concretizaram, quem oferece acesso a isso é a ficção. Ela ensina ao historiador - para usar o Walter Benjamin - que não há apenas o vencedor e o vencido, mas, entre eles, um mundo de possibilidades que as pessoas estavam imaginando ou tentando viabilizar em uma época. Hoje eu diria que a literatura ajuda a revelar algumas coisas da tradição esquecida - no sentido conferido pela Hannah Arendt - da República no Brasil. No momento em que se reconhece que a ficção é capaz de dar algo que os historiadores não atingem sozinhos, a nossa relação com ela se torna mais respeitosa, e entendemos como a literatura opera com ferramentas próprias. Isso é rico. 
Comparando a dissertação de mestrado com sua tese de doutorado, parece ter havido uma inversão interessante em termos de forma e conteúdo. Em Os senhores das Gerais, a literatura e a música aparecem na forma de citações e epígrafes ilustrativas ou secundárias, enquanto a Teoria Política ocupa o corpo principal do texto. Já em Lembranças do Brasil, o corpo do texto é marcado pela ficção de Guimarães Rosa, ao passo que a Teoria Política se concentra nas notas de rodapé...

Isso foi fruto de uma decisão. Se eu pusesse a Teoria Política no corpo do texto, não funcionaria. Naquele momento, eu estava apanhando dos dois lados: do IUPERJ, que me criticava fortemente, e das Letras, onde havia uma dura resistência, porque as duas áreas estavam muito separadas. 0 José Murilo fez um texto muito bonito sobre esse assunto, chamado "0 historiador às vésperas do terceiro milênio", no qual afirma que nós precisamos de duas coisas para flexibilizar o nosso campo: a imaginação e a multiplicidade das fontes. Contudo, naquela época, os pesquisadores não estavam confortáveis com essa abertura e tampouco convencidos de que a historiografia é um gênero literário, como diria o Carlo Ginzburg. Talvez nosso campo ainda se encontrasse muito atravessado pela tradição marxista. Afora isso, tínhamos em outra ponta a influência francesa entrando fortemente no Brasil, a qual não tem a menor simpatia por tal abertura. Os Annales, por sua vez, almejavam a História da longuíssima duração, dos imaginários, do coletivo... Foi mais ou menos nessa altura que conheci a historiografia inglesa e a norte-americana, as quais apresentam outros caminhos.

\section{Existem muitas diferenças entre a tese propriamente dita e a versão publicada de Lembranças do Brasil? Como foi a recepção desse trabalho?}

Não. Após a defesa o IUPERJ considerou que eu devia publicar a tese e eu a mantive como estava. Hoje, eu mudaria algumas coisas. Quanto à recepção, foi diferente da recebida na ocasião do lançamento de Os senhores das Gerais. Naquele caso, o tema provocou uma repercussão na imprensa. Já o acolhimento de Lembranças do Brasil se restringiu ao âmbito acadêmico e me abriu possibilidades de interlocução muito ricas com outras áreas do conhecimento, principalmente nas Letras. Finalmente, eles consideraram que era possível realizar aquela comunicação entre as áreas. A Cátedra Padre Antônio Vieira de Estudos Portugueses, da PUC-Rio, foi essencial para isso.

A partir dali, eu e o Newton Bignotto começamos a construir juntos uma reflexão sobre a tradição republicana e sobre a República no Brasil, trazendo historiadores, cientistas 
políticos e o pessoal das Letras. Para mim, isso significou um trânsito importante. Mas não quer dizer que todo mundo tenha achado bom. Entretanto, permitiu seguir adiante e colocar em conversa essas áreas de uma forma mais confortável, pois ainda havia uma resistência grande, sobretudo a partir do campo historiográfico, que possui fronteiras menos porosas. Recebi muitas críticas, algumas bastante pertinentes e outras mostrando a relutância quanto ao uso da literatura. Acredito que há lugares inacessíveis para o historiador e que a ficção é o caminho para se chegar a eles. Passei muito tempo, depois de Lembrança do Brasil, tentando mostrar que eu também sabia lidar com o documento.

\section{Depois do doutorado, pode-se dizer que você manteve essa interlocução com a literatura, ao estender seu método de análise e de decomposição do Grande sertão: veredas para autores como Graciliano Ramos e Euclides da Cunha?}

Sim, esse é um caminho para se pensar o conceito de sertão.

\section{Nesse âmbito, há também uma discussão sobre o imaginário republicano e a imaginação espacial, estabelecida por uma série de pesquisadores da área do pensamento social que articularam a Geografia e a História com a literatura. Como você analisa esses trabalhos?}

Existem grandes trabalhos. Um dos pioneiros é o belo artigo da Janaina Amado, "Região, sertão, nação", que saiu publicado na Estudos Históricos. Tem muita coisa boa. Por exemplo: A pátria geográfica: sertão e litoral no pensamento social brasileiro, da Candice Vidal e Souza; Um sertão chamado Brasil, da Nísia Trindade, que é uma beleza; A terra como invenção. O espaço no pensamento social brasileiro, do João Marcelo Ehlert Maia; Brasil, ficção geográfica, da Luciana Murari... Esse debate mostra que os pesquisadores estavam conversando. A Fundação Casa de Rui Barbosa promovia muito o contato entre as áreas, e o Grupo de Pensamento Social, na Anpocs, foi decisivo nesse ponto. Seus membros não aliviam, fazem críticas duras aos trabalhos apresentados lá, e são formidáveis, principalmente por permitirem que todos discutam e pensem juntos. Talvez por isso seja um dos grupos mais antigos e intelectualmente mais generosos da Anpocs. Lá, a discussão fertilizou e foi um dos lugares onde tive condições de crescer. 


\section{Enquanto cursava o doutorado, você já lecionava no Departamento de História da UFMG. 0 fato de toda a sua pós-graduação ter-se concentrado na Ciência Política} não a fez considerar uma migração como docente para essa área?

Em alguns momentos cogitei essa possibilidade. Entretanto, por mais fascínio que eu tenha pela Teoria Política, gosto muito de trabalhar com a História. Afora isso, descobri o meu lugar no mundo, em conjunto com o Marcelo Jasmim, que é a História das Ideias. O velho IUPERJ deu régua e compasso para esse campo no Brasil, pois de lá saíram, além do próprio Marcelo, 0 Ricardo Benzaquen, o Luiz Eduardo Soares, a Isabel Lustosa, a Helena Bomeny, a Nísia Trindade... Todo mundo estava ali, mais ou menos na mesma época. E antes e acima de todos nós, a Ângela de Castro Gomes - que também passou por lá - foi fundamental nesse processo, ao redigir um trabalho magnífico e poderoso para questionar o conceito de populismo e mostrar seus limites como uma categoria política que acaba por desqualificar todo um período da história do Brasil.

\section{IUPERJ promoveu o encontro entre pesquisadores de diversas áreas das}

\section{Ciências Sociais...}

Sem dúvida. Havia muita coisa florescendo lá, e isso fornecia entradas fundamentais para se escapar da historiografia francesa, que vinha de São Paulo, e trilhar caminhos propostos pela produção inglesa, norte-americana e alemã.

Parte dessas pessoas que se formaram no IUPERJ foi lecionar na PUC-Rio e pôde desenvolver essas ideias. Na PUC, como no IUPERJ, havia essa disposição para funcionar como um lugar de fronteira - espaço de encontro entre áreas de conhecimento entre si diferentes. Existia uma relação muito próxima que agregava História, Filosofia e Letras, nesse caso estimulada pela cátedra portuguesa da dona Cleonice Berardinelli. A partir dali começaram a se organizar eventos - como o Seminário Hannah Arendt, promovido pelo filósofo Eduardo Jardim - aos quais compareciam pesquisadores da História, da Ciência Política, da Filosofia, das Letras... Portanto, o IUPERJ e a PUC-Rio foram essenciais para o desenvolvimento a História das Ideias no Brasil.

\section{Todo esse movimento de integração entre pesquisadores gerou o seminário Decantando a República, realizado em 2001 também na PUC-Rio, não é? Qual era o objetivo desse encontro?}

Exatamente. A proposta era abrir espaço para o novo e aproximar intelectuais a partir da suposição de que a literatura fornece um lugar para se pensar o Brasil, o qual a História e 
a Ciência Política precisam se esforçar para entender. Na França, por exemplo, os estudiosos pensam muito seu país através da literatura. Já aqui, pensamos por meio da canção. A oralidade sempre foi uma presença marcante entre nós devido às dificuldades objetivas enfrentadas na constituição da nossa formação histórica: a persistência e a amplitude social do analfabetismo e a existência de uma população em larga medida semi-escolarizada; a força das características de uma sociedade em que as relações privadas dão o tom e dominam o cenário mesmo no âmbito da esfera pública. A canção é um dos meios por onde o Brasil se entende, se inventa e fala de si e, portanto, onde há um diálogo na cena pública. Ou seja, no nosso caso, a canção é capaz de fornecer uma interpretação do Brasil, como a literatura. Dessa forma, se quisermos pensar nosso país, precisamos lidar com essa linguagem.

A partir disso, consideramos fazer uma experiência bastante arriscada: convidar 30 intelectuais de diferentes áreas para analisar canções, sendo que 90\% deles jamais tinham produzido nada nesse âmbito. Assim surgiu o Decantando a República, algo muito legal. 0 pessoal da música me criticou muito. Eles advertiam: "Ah! Mas faltaram os tambores, o ritmo, a percussão..." É claro que sim. Todo mundo ali estava aprendendo. Recentemente eu conversei com a Nísia Trindade sobre organizarmos uma nova edição. Se repetirmos agora, é lógico que vou falar da canção como melodia; trazer o rap, que apareceu pouquíssimo naquela ocasião. Hoje podemos imaginar uma série de possibilidades. Contudo, inicialmente, era preciso colocar o ovo em pé. A gente não sabia nada, estávamos apenas começando e a PUC felizmente aceitou nos receber.

\section{Mas naquele momento o José Murilo de Carvalho já havia escrito um texto sobre o Gabriel, o Pensador, não é?}

Sim. Inicialmente, eu reuni quatro jovens estudantes - um deles, o Bruno, continua comigo até hoje - e juntamente com o Newton Bignotto fizemos uma pesquisa enorme sobre a canção popular e gravamos uma série de 12 CDs chamada Decantando a República, que entregamos aos convidados. A partir dali, esses intelectuais escolheram os artistas que queriam analisar, e o José Murilo resolveu escrever sobre o Gabriel, o Pensador. No conjunto das reflexões, há textos que são antológicos até hoje. 0 projeto foi legal por reunir todas as áreas e por tentarmos fazer ali uma descoberta de lugares onde está a imaginação e a interpretação do Brasil.

\section{Como esse seminário acabou se convertendo em um projeto duradouro?}

O Decantando a República foi realizado em 11 de setembro de 2001, dia em que aconteceram duas coisas: os ataques às Torres Gêmeas e o surgimento do Projeto República. 
Recordo que houve, inclusive, uma ameaça de bomba na PUC-Rio. Foi muito impressionante tudo aquilo. Quando acabou o seminário, eu e o Newton Bignotto pensamos: "Nós conseguimos montar uma estrutura. Agora não podemos perder o que foi construído e simplesmente dizer adeus a esses quatro jovens pesquisadores que nos ajudaram." Então criamos o Projeto República e buscamos patrocínios para garantir bolsas de estudo aos envolvidos. A partir dali, o projeto tomou corpo e permanece vivo até hoje.

Outro fruto desse trabalho foi um programa de rádio que criamos aqui na UFMG, também chamado Decantando a República, coordenado pelo Bruno Viveiros, no qual procurávamos evidenciar esse lugar de interpretação e o fluxo que a canção faz entre as diferentes linguagens, como a da poesia do livro e a da poesia cantada.

Com o desenvolvimento desses estudos, encontrei na nossa história personagens como Manuel Inácio da Silva Alvarenga, poeta do século XVII, em cuja obra há um trânsito entre 0 verso da poesia do livro e a tonalidade da serenata. No século XX, Chico Buarque, Vinicius de Moraes, Tom Jobim e Maria Bethânia reafirmaram a isonomia entre as duas classes de linguagem poética praticadas no país - a escrita e a cantada. E fizeram isso muito bem. Esse é um ponto que me interessa estudar, todavia tudo está em volta de uma mesma problemática

- eu estou sempre dando voltas em torno de um mesmo objeto, que é o Brasil. É como dizia o Carlos Drummond de Andrade: "Meu país, essa parte de mim fora de mim constantemente a procurar-me".

\section{Seu interesse pela canção popular faz com que você tenha de lidar com uma tradição de estudos feitos por musicólogos, por pessoas das Letras, como o Luiz Tatit e o José Miguel Wisnik, ou ainda por cientistas sociais, como a Santuza Cambraia Naves e a Elizabeth Travassos. Como foi, para você, se situar nesse campo?}

Exatamente. Afora isso, tive que lidar com o campo historiográfico, que achava um horror o que eu estava querendo fazer, porque cobrava dos candidatos à pós-graduação o conhecimento musical e a leitura de partitura. Eu refutava: "Ô gente, não é bem isso que nós precisamos. Pode ser bom o pesquisador saber ler música, mas não necessariamente." Alguns historiadores ficavam muito indignados, como se eu quisesse descaracterizar a área de conhecimento ou como se nada fosse próprio da História.

Por outras razões, os musicólogos e a turma das Letras também achavam que não funcionaria. Evidentemente, não defendi isso sozinha. A Santuza Cambraia Naves foi uma figura importantíssima nessa discussão. Ela, o José Miguel Wisnik e o Luiz Tatit me ensinaram 
o caminho das pedras e me permitiram uma abertura enorme. Eu lembro nitidamente do Tatit me aconselhando: "Você precisa achar um caminho próprio para entender a questão da música." Atualmente, História e Letras estão confortáveis para abordar essa linguagem e temos produções formidáveis, como as da Tânia da Costa Garcia, professora da UNESP, ou do Marcos Napolitano e do Walter Garcia, na USP.

\section{0 trabalho do historiador com a canção popular apresenta o mesmo problema em relação à literatura, ou seja, é preciso evitar uma leitura meramente documental, não é?}

Sem dúvida. E ainda devemos respeitar o que é próprio daquela linguagem. O Wisnik repetiu isso diversas vezes para mim: "Se você não respeitá-la, ela será diluída e a História engolirá tudo." As mediações e as indicações de leituras que Wisnik, Tatit, Nestrovski fazem nos seus trabalhos foram fundamentais para que eu aprendesse a lidar com a canção, assim como, no passado, foram essenciais as lições da Eneida Maria de Souza e do Wander Melo Miranda para que eu trabalhasse com a literatura.

Hoje, quando vejo livros saírem apenas com letras de Caetano Veloso, eu acho o máximo e comemoro: "Que bom que agora pode!" Uma das críticas feitas ao Decantando a República é que, naquela ocasião, só trabalhamos com letras. Eles tinham razão. Hoje, teríamos que discutir a capa do disco e toda a concepção que o autor pensou para a sua obra. Contudo, naquela época, eu ainda estava aprendendo...

\section{O seu interesse pelo sertão na literatura e pelas origens da matriz republicana acaba fazendo você se voltar, mais tarde, para o estudo das Minas Gerais no século XVIII, não é?}

Sim. Eu diria que apenas por volta de 2001 encontrei o que eu perseguia desde os anos 1970, ou seja, "aquela parte de mim fora de mim", um caminho para pensar a tradição republicana no Brasil. Estudar o Guimarães Rosa me ajudou a entender um pouco qual era a discussão da República que faltava. E fui estimulada também pelo Newton Bignotto, que me chamou para essa discussão. A partir de então, construímos dois livros: Pensar a República e Retorno ao republicanismo. Nessas obras reunimos historiadores, filósofos, cientistas políticos e estudiosos da literatura em torno dessa temática. Ao se considerar que os valores do mundo público emergem na canção e na literatura, o republicanismo pode fornecer uma chave para se pensar o Brasil. 
Uma questão importante para mim é indagar: "Que República nós temos?" E não me interessa pensar apenas no sentido da sociologia "da falta", em termos de nós não somos isso ou aquilo. Eu não quero refletir dessa maneira. Minha vontade é entender essa matéria, que é difićlima, porque possuiu uma discussão centrada no século XIX. Hoje, quase todo mundo diz que é republicano, só que a República soa como uma palavra oca, porque ninguém sabe muito bem o que é. 0 meu problema era estudar o Brasil para pensar isso.

Além disso, eu tinha um desconforto pessoal com a maneira como a historiografia de Minas Gerais, em geral, trata da Conjuração Mineira. Como eu não me dedicava ao século XVIII, ficava cheia de dúvidas. Esse grupo que começou a estudar a República e a tradição do republicanismo reforçava muito a necessidade de enfrentar esse impasse, afirmando: "Observe, tem o Brasil. Não adianta nós ficarmos pensando só lá fora." Então, juntos, avançamos muito. 0 último livro que fizemos foi Matrizes do republicanismo, no qual identificamos as matrizes formadoras da tradição republicana: a romana, a renascentista, a francesa e a norte-americana - que ficou por minha conta. Avançamos muito, porém continuou existindo o problema do Brasil.

0 que me fez entender, finalmente, o percurso que deveria seguir foi a obra do Evaldo Cabral de Mello. Isso porque ele coloca três situações que têm a ver comigo: uma, história é empatia - contar uma história é como "calçar os sapatos do morto", ele diz -; outra é que ele ensina a pensar o Brasil a partir das margens; e a terceira é o uso da narrativa. A narrativa é uma forma de escrita repleta de perigos, mas é próprio do gênero reter do passado algo de perturbador: a repetição do vivido, o retorno das possibilidades perdidas. Então, a partir dos debates no grupo dos "Repúblicos" e da leitura da obra do Evaldo Cabral, comecei a acreditar que era possível pensar sobre a questão da República no Brasil.

Depois, na minha tese de titular, que gerou o livro que estou terminando agora, voltei aos séculos XVII e XVIII, com duas perguntas. Uma, como a palavra "República" chegou até nós, embarcada em Portugal, ainda no século XVII; e como, surpreendentemente, ela se aclimatou no ambiente político da América portuguesa, desenvolveu novos sentidos, condensou inúmeros significados e, com o passar do tempo, ganhou peso e relevância entre os funcionários do rei e entre os colonos. A outra pergunta: como foi que essa "tradição republicana" desapareceu quase sem deixar vestígio? Afinal, ao se encerrar o século XVIII, um repertório republicano começou a ser praticado na América portuguesa. Esse repertório se formou não apenas no plano da ordenação de ideias e constituição de vocabulário, mas também no âmbito das práticas simbólicas e da imaginação. E ele dialogou direta ou indiretamente com as cinco matrizes da tradição republicana - a romana da Antiguidade, a italiana do Renascimento, a inglesa do século XVII, a francesa dos séculos XVIII e XIX, e a americana do mesmo período. 
0 problema que se coloca agora é que o Evaldo diz que a narrativa resolve, mas se esquece de nos dizer o quanto é difícil fazê-la. Nesse livro novo, tentei enfrentar mais decididamente esse obstáculo. Nós, historiadores, somos uma gente esquisita. Nos intrometemos num tempo que não é o nosso, abrimos portas e escarafunchamos gavetas que não nos pertencem, queremos sentir com sentimentos de outras pessoas e fazer novas perguntas a uma sociedade que em geral se desintegrou há muito tempo atrás. Contudo, não temos a liberdade fascinante da literatura. A narrativa, por sua vez, viabiliza partirmos do particular para discorrermos sobre um momento maior. Ela possibilita pensar um personagem no tempo que lhe foi dado viver, e não no nosso. 0 historiador se vê na contingência de fazer novas perguntas sobre o passado e, em especial, sobre o sentimento do tempo vivido pelos homens. Para respondê-las, ele precisa de novas fontes de pesquisa e de ouvir de novo e de outra maneira o que os documentos têm a dizer.

Entretanto, a narrativa é complicadíssima. Um dia eu disse para o Evaldo: "Esse negócio de fazer narrativa é um inferno. Não estou conseguindo." Ele riu e respondeu: "Se a senhora lesse menos teoria e mais literatura, iria continuar achando difícil, mas não tanto." Ele tem toda razão. Um dos caminhos realmente é esse: ser capaz de operar com a riqueza que a literatura oferece e que a historiografia inglesa usa bastante. Perdemos um pouco disso aqui em função da tradição marxista. Se pensarmos em Visão do paraíso, do Sérgio Buarque de Holanda, veremos que ele combinou literatura com história e fez o que dizia ser a biografia de uma ideia. Não é à toa que a obra é aquela beleza. Em Monções, ele desenvolveu o mesmo procedimento, ou seja, operou com a narrativa e mostrou que a combinação é possível.

Atualmente, podemos destacar dois grandes historiadores no Brasil, que são mestres da narrativa: Alberto da Costa e Silva e Evaldo Cabral. O Alberto da Costa e Silva é um narrador e poeta. Na biografia do Castro Alves que escreveu, a maneira como ele costura a poesia, a história e uma interpretação do pensamento abolicionista no fio da vida de um personagem e em um único livro é extraordinária - uma coisa muito bonita de ler. Já o Evaldo Cabral segue outro caminho, não menos requintado. Ele constrói seu estudo histórico como um romancista constrói seu romance, preservando a intriga. Por exemplo, o nome e o sangue: uma parábola familiar no Pernambuco colonial é um livro que você lê em camadas. Isso porque um sujeito que não é da nossa área o entende como uma aventura policial sobre alguém que falsifica um documento para conseguir se livrar do Santo Ofício. Na segunda camada, é possível entender como é viver durante o período colonial, em Pernambuco, no século XVII. E, na terceira, aparece a desfaçatez da elite. 0 Evaldo constrói isso tudo numa narrativa. Considero excepcionais todos os livros dele. Em razão disso, porém, O nome e o sangue é uma aula de como construir possibilidades de ver o Brasil pela margem, e a partir de um personagem. Como ele consegue isso?! [risos] 


\section{A partir dos anos 1970, o linguistic turn passa a considerar que a narrativa explicita o que a escrita da História tem de gênero literário. Como os historiadores podem lidar teoricamente com o desafio de repensar as premissas de seu próprio trabalho, ancorado no registro e no relato escrito?}

Uma possibilidade é esta maneira, como o Evaldo Cabral fez em 0 nome e o sangue, ou seja, criando camadas. Afora isso, há momentos em que é preciso ter um acordo com o leitor, diferente do pacto ficcional, e avisá-lo que se está especulando. A narrativa permite isso, sobretudo quando se tem poucas fontes.

Por exemplo, na história da Conjuração Mineira há uma personagem feminina pouco tratada, chamada Hipólita. Ela não era uma musa, igual a Marília ou Dorotéia, mas alguém que participou da discussão acerca da conspiração. A fazenda dela se localizava no meio do caminho entre Vila Rica e o Rio de Janeiro e lá aconteciam reuniões dos Conjurados. Quando chegou a notícia da prisão do Tiradentes, ela enviou um bilhete para o tenente-coronel Francisco de Paula Freire de Andrade, comandante do corpo militar dos Dragões e provável chefe militar da rebelião, ordenando: "Deflagre. Dê o viva ao povo e bote a tropa na rua, porque Tiradentes foi preso." E concluiu afirmando: "Quem não tem competência para as coisas, que não se meta nelas." A meu ver, é uma figura importante, da qual sabemos pouco. Ao abordar tal assunto, posso esclarecer ao meu leitor: "O que leva essa mulher a participar da política? Ela está diante do proibido." O documento que citei está no Auto da Devassa e preciso convidar o leitor a pensar sobre aquela personagem.

Eu não posso ficcionalizar a personagem. Contudo, posso dizer que, naquele momento, as mulheres não eram necessariamente impedidas de trabalhar e que a maior proibição era se envolver na política. 0 que atraiu essa senhora? Talvez o proibido. Quando faço isso, não tenho um documento para me apoiar, entretanto posso apresentar algumas características dela. 0 Visconde de Barbacena sabia quem era a dona Hipólita e, de todas as mulheres casadas da Conjuração, ela foi a única que perdeu tudo. Em geral, a repressão da Coroa estabelecia o confisco apenas da parte do marido. Quanto a Bárbara Heliodora, por exemplo, o governo recolheu apenas metade de seus recursos materiais. A ideia do Visconde de Barbacena era dizer a dona Hipólita: "A senhora vai ver!" Ele só não sabia com quem estava lidando, pois ela passou os anos seguintes infernizando a vida da Coroa: ela mente, suborna funcionários, falsifica documentos, apronta todas. Ela era uma mulher muito rica, da comarca do Rio das Mortes, e em 1808 havia recuperado 90\% das suas propriedades. Eu tenho os dados que envolvem subornos e falsificações e posso convidar o leitor a pensar um pouco sobre essa personagem. Para isso o historiador precisa ter imaginação, e a narrativa oferece caminhos a ela. É preciso 
ainda saber perguntar para o documento. Ele, em si, dizia Sérgio Buarque de Holanda, não conta nada. Entretanto, pode revelar tudo, desde que se saiba questioná-lo. A imaginação possibilita fazer isso e propor a reflexão sobre um personagem, evento ou situação.

Outra coisa que achei interessante tentar fazer no meu novo livro foi analisar, nos Autos da Devassa, a relação de todo o vestuário do Tomás Antônio Gonzaga. Ele era vaidosíssimo e gastava tudo que tinha em roupas muito extravagantes para nós hoje, como um casaco verde-periquito. A partir disso, tentei criar um capítulo que se inicia com ele se preparando para ir a uma missa, na qual vai tentar namorar a Marília. Então, eu digo para o leitor: "Essas roupas são dele, estão lá nos Autos da Devassa, no anexo. Ir à igreja para namorar era usual. Já a situação do poeta se vestindo para ir à missa, é provável, mas não sabemos se foi assim."

\section{Este é um artifício que os biógrafos têm empregado em suas obras. Mas é possível separar exatamente os momentos em que o autor está efetivamente fantasiando?}

Sem dúvida. Para estabelecer essa divisão, basta convidar seu leitor a pensar a situação e avisá-lo sobre o que se está fazendo.

\section{Existe uma ideia, exposta pelo Hayden White, por exemplo, de que a própria estrutura narrativa que organiza o conjunto do relato histórico é imposta. Assim, ela seria ficcional. Você concorda com isso?}

Nesse sentido, sim. Na História, nunca vamos saber tudo o que aconteceu, teremos apenas pedaços e fragmentos que já vêm alterados pelo tempo. Contudo, podemos informar isso ao público. A partir do que pensava a Hannah Arendt, o leitor também precisa ser informado sobre aquilo que o autor entende como a verdade da história, ou seja, devemos apresentar um evento na cena pública que ninguém possa dizer que não aconteceu. Essa é a verdade factual: a ostentação pública de fatos que não podem ser modificados pela vontade de quem ocupa o poder, nem podem ser demovidos a não ser por força de mentiras cabais. Por essa razão, seu contrário não é o erro, nem a ilusão, nem a opinião, e sim a falsidade deliberada, a mentira. Em tempos de "fatos alternativos", essa definição dela é bastante importante. Por exemplo, se documentos do período da ditadura militar revelam um determinado fato - como o Relatório Figueiredo denuncia toda sorte de crueldades que foram cometidas contra indígenas no país -, o Estado, ou o governante do momento, não pode simplesmente dizer que aquilo não aconteceu. 
A maneira como podemos contar o passado para quem não o vivenciou e cujo conhecimento vai ajudá-lo a compreender melhor o seu próprio tempo - que é o compromisso ético do historiador - passa por esse processo. 0 público precisa saber quais são os limites da História. Isso é diferente de afirmar: "Essa é a verdade. A Conjuração Mineira foi assim." Não foi exatamente dessa forma, a obra conta apenas um pedaço da história. Abrir essas portas é difícil, arriscado, e tira o historiador da zona de conforto. Contudo, é primordial. E, se temos o privilégio de esclarecer essas coisas, devemos exercê-lo.

Eu tenho um sobrinho de 15 anos com o qual comentei sobre isso, e ele questionou: "Quer dizer que, finalmente, você está assumindo que o historiador é um grande fofoqueiro?" Eu retruquei: "Olha, não é bem assim." [risos] Mas, afora o atrevimento, podemos pensar nisso, pois afinal temos um ofício no qual vamos a um tempo em que não vivemos e lemos cartas, depoimentos... E depois saímos contando para todo mundo.

O Chico Buarque tem uma canção chamada Futuros amantes, que talvez tenha feito pensando em seu pai. Nela, ele fala sobre a delicadeza e a dificuldade do ofício do historiador. A canção narra o Rio de Janeiro como uma cidade que, no futuro, será submersa e na qual escafandristas irão mergulhar para resgatar sua história. Alguém precisa perguntar ao Chico se ele leu aquele texto sobre a pesca das pérolas da Hannah Arendt. Os escafandristas, enfim, são os historiadores. Eles mergulham e trazem pedaços de papel, fragmentos de um passado que sábios tentarão decifrar em vão. São fragmentos de cartas e poemas. Então, o autor usa o pacto ficcional e nós acreditamos: ele diz que um dia descobrirão que aqueles papéis são cartas de amor que o autor escreveu para sua amada. Porém, pode ser apenas a conta de telefone ou outra coisa qualquer. Nós estamos acreditando no verso porque o Chico é um fingidor. Em nosso caso, não podemos fazer isso sem alertar o leitor. Os biógrafos preocupam-se bastante com isso, e o Lira Neto, por exemplo, costuma advertir: "Eu não posso dizer que o personagem fez algo se não tiver certeza disso. Então, preciso dizer ao leitor que talvez tenha ocorrido." É necessário informar que se está especulando.

\section{Em alguns momentos, a singularidade de uma informação encontrada em um documento pode aguçar o desejo do historiador de fantasiar?}

Em alguns casos, sim. Por exemplo, ao lidar com dados referentes à Conjuração do Rio de Janeiro, ocorrida em 1794, senti como se estivesse diante da ficção. A história fornecia uma narrativa tão rica que não precisava da ficção para o leitor imaginar o que ocorria.

Naquela conjuntura, um grupo de letrados conseguiu colocar um vocabulário republicano em circulação no centro da cidade do Rio de Janeiro e fez as pessoas discutirem aquele 
tema. 0 Conde de Resende, então governador, tentou reprimir essa onda prendendo pessoas, mas não conseguiu porque os acusados se defendiam alegando: "Eu ouvi um grupo falando sobre isso lá no Mercado do Peixe..." Então ele mandava prender o tal grupo, e os novos acusados se justificavam assim: "Ficamos sabendo disso porque ouvimos no chafariz do Mestre Valentim..."

É incrível como as ideias circulavam, parece existir uma internet em funcionamento no século XVIII, como disse o Robert Darton para o caso de Paris... Nos Autos da Devassa, vem um acusado e declara: "Eu sou a favor da República porque nela vou viver e comer bem." Já outro argumenta: "Eu sou a favor porque ela paga o que deve às pessoas." Percebemos assim como as pessoas comuns sintonizavam o vocabulário republicano com seus próprios assuntos cotidianos, convocavam seus interesses imediatos e reagiam à sua maneira. Esses letrados liam jornais clandestinos e livros que traduziam e, depois, colocavam isso em circulação nas boticas, porque boa parte deles eram médicos que tinham relações com farmacêuticos. 0 cliente ia então à botica comprar um remédio, a conversa rolava e ele levava aquele conteúdo adiante. Quando se mapeia esses depoimentos, percebe-se que havia um circuito incrível funcionando. Essa é uma das grandes novidades da Conjuração, e ali um vocabulário rico do republicanismo aparece em cena. Se o historiador apenas contar isso, sem apresentar documentos, ninguém acredita.

\section{A ficção, nesse caso, fica a cargo do leitor?}

Sem dúvida. Um deles me contou que, após ler o livro, foi até a parte de trás do chafariz do Mestre Valentim para ver se dava para ouvir mesmo. [risos] Ele me revelou: "Funciona essa maluquice que você imaginou!" Eu não imaginei nada. Está nos Autos da Devassa. Mas a imaginação é sim uma ferramenta valiosa para o historiador.

\section{Essa história que você encontrou na documentação acabou sendo mais surpreendente do que as hipóteses que você poderia levantar, não é?}

Exatamente. Se eu fizesse, os historiadores poderiam dizer: "Olha a Heloísa! Está vendo? Essa proximidade dela com a literatura acabou mal, porque ela inventou! " A dimensão imaginativa que o documento fornece nos faz olhar e pensar: "Não é possível isso ter acontecido no Rio de Janeiro em 1794! Como?!" Então, é necessário ter alguns cuidados e perguntar: "Pode ter acontecido? Talvez? Existem outras fontes?" A partir daí, você informa seu leitor. 
Eu tenho outro exemplo referente a essa questão das fontes. Quando o Evaldo Cabral estava estudando a Guerra dos Mascates, ocorrida em 1711, ele descobriu como havia chegado a Pernambuco a ideia de se criar a República de Veneza. Fez isso localizando as famílias que vieram fugidas da Itália e trouxeram aquelas formulações de republicanismo. Em 1721, em Minas Gerais, o Conde de Assumar escreveu um documento dizendo que a Revolta de Felipe dos Santos pretendia instalar naquela região uma república à moda de Veneza. Entretanto, nenhum pesquisador prestou muita atenção nisso. 0 primeiro historiador da revolta mineira olhou para aquele documento e concluiu: "República de Veneza, em 1721, nas Minas Gerais, só na cabeça do Conde de Assumar. Ele escreveu esse documento para justificar a repressão que fez. Portanto, ele inventou."

Todos os historiadores que o seguiram embarcaram nisso. Contudo, como eu havia estudado os dois eventos, perguntei ao Evaldo: "Você considera possível que aqueles grupos da Guerra dos Mascates tenham migrado da Bahia e de Pernambuco para Minas Gerais?" Ele riu, pegou o material dele e me mostrou o nome dos líderes daquela revolta que haviam seguido exatamente esta rota a fim de escapar da repressão. Então, de fato, pode ter acontecido. Muita gente foge pelo caminho do sertão. Portanto, é possível que as ideias de Veneza tenham chegado a Minas Gerais dessa maneira. No meu trabalho, eu expus o nome deles e descrevi tudo, porém indiquei que era uma boa hipótese. Não posso prová-la. 0 meu público, eu espero, entenderá que usei toda a documentação disponível. Se eu estivesse fazendo ficção, estaria mais livre e narraria toda a saga do cara saindo do Nordeste em direção a Minas Gerais, levando as ideias republicanas.

\section{Neste ponto estamos falando da metáfora de seguir os fios e rastros a partir das fontes, concorda?}

Exatamente. Algo que ajuda bastante, mas que só é possível porque existe uma historiografia feita sobre aquilo, como a do Evaldo e de outros historiadores que abordaram esses eventos. Quando se reúne tudo isso, tais possibilidades se abrem. Isso não aconteceria se não tivéssemos no Brasil uma historiografia tão vigorosa quanto a atual. Para escrever Brasil: uma biografia, Lilia Moritz Schwarcz e eu lemos muito e compreendemos o poder da nossa produção historiográfica para iluminar o passado e fornecer outros caminhos. Sem essa base, ninguém cria novas possibilidades. Portanto, é necessário reunir as três dimensões: a imaginação do historiador, as fontes e a historiografia existente. 


\section{Na ocasião do lançamento de Brasil: uma biografia, você e a Lilia Moritz Schwarcz responderam diversas vezes que a escolha do subtítulo foi uma decisão editorial.}

\section{Como se deu isso?}

Exatamente. Nós compramos a ideia do Luiz Schwarcz. Quando ele começou a ler, concluiu: "Gente, isso é uma biografia." Então, eu refutei: "Não, imagina, Luiz! Nós não sabemos fazer isso." Depois, Lilia e eu fomos olhar o que havíamos escrito e, de fato, trazíamos à cena personagens notórios e anônimos para interrogar o que os episódios daquelas vidas têm a dizer sobre as coisas públicas, sobre o mundo e o tempo em que vivemos. Ao fazer isso, encontramos alguns casos muito legais. Por exemplo, a Zeferina, que dirigiu a resistência no Quilombo do Urubu, é uma grande personagem. Eu disse depois para o João José Reis, que foi a fonte onde eu a descobri: "Você precisa fazer a biografia dela." Ele respondeu: "Só se você achar outros documentos, porque tudo que eu sei sobre ela já está no meu livro." Essas vidas ao rés do chão iluminam o contexto em questão. Portanto, existia mesmo esse lado da biografia. A meu ver, esse gênero permite flexibilizar os campos do conhecimento. Foi o que o Sérgio Buarque de Holanda fez quando dizia estar produzindo a biografia de uma ideia em Visões do Paraíso - uma biografia construída sobre as diversas tópicas do imaginário edênico do Novo Mundo, onde ele combinou Antropologia, literatura e História.

\section{0 título assim se explica, também, porque ele foi concebido inicialmente como um livro para atender ao público anglófono, não é mesmo?}

Sim, para o público da Inglaterra. Entretanto, saiu primeiro em português e depois na Espanha, em Portugal, na Argentina, no Chile e no México. Agora, em 2017, será publicado nos Estados Unidos e na China. Eu achei o máximo! Até comemorei com Lilia: "Conquistamos as Muralhas da China!" E, finalmente, também sairá na Inglaterra.

Existe um pedido para que Lilia e eu nos debrucemos novamente sobre o livro e façamos uma atualização que o traga até os dias de hoje. Achamos importante fazermos isso e temos conversado a esse respeito. Entretanto, eu estou terminando o livro sobre a tradição esquecida do republicanismo, e ela, uma biografia do Lima Barreto. A conclusão que precisamos pensar diz respeito às mudanças que ocorreram no país. Entre 2015 e 2017, uma mudança vertiginosa ocorreu, a qualidade da nossa democracia foi posta em dúvida, os procedimentos democráticos entraram em crise. 0 que aconteceu? A Lilia avalia - e eu concordo com isso - que se fizermos após a conclusão um acréscimo do tipo "E assim se passaram vinte anos (que na verdade foram só dois)", devemos começá-lo dizendo: "O livro Brasil. uma 
biografia termina dessa forma. Naquele momento, as ferramentas que tínhamos para pensar eram essas." Então, iniciaríamos uma reflexão bastante difícil que traria o livro até o recente impeachment e o presente momento.

\section{Quando foi concluída a versão atual do livro?}

Nós o entregamos em janeiro de 2015 e, na véspera, quando estava indo para a gráfica, pedimos ao Luiz: "Deixe a gente botar um pedacinho a mais?" Eu me lembro da Lilia chegando de viagem e dizendo: "Heloísa, ocorreram essas manifestações. Precisamos acrescentar um P. S. no livro..."

Acho que temos que lidar com essa questão a partir de uma pergunta que, de certa forma, está no último capítulo de Raízes do Brasil, do Sérgio Buarque de Holanda. Ele vivia uma conjuntura fascista terrível quando o redigiu e questionava por que a democracia era tão difícil em nosso país. Considero que essa mesma pergunta está colocada para nós. Ou seja, 30 anos após termos construído uma sociedade com instituições democráticas e uma Constituição sólida, nos perguntamos por que estamos vivendo isso agora. Vocês podem me dizer: "Mas não é só o Brasil." Eu concordo. Em relação ao contexto em que vivia o Sérgio Buarque de Holanda, também é verdade e ele já questionava o mesmo que nós: por que é tão difícil a nossa experiência democrática? Não sei daqui a 30 anos. Todavia, certamente, agora não podemos construir uma narrativa afirmando que a sociedade brasileira é democrática e que 0 problema são os militares. A nossa sociedade não tem a cultura democrática que acreditávamos. Ou, pelo menos, parte dela não tem.

\section{É interessante pensarmos como essa discussão a que vocês se propõem agora preserva a questão motivadora inicial da sua trajetória de historiadora: compreender as questões da política contemporânea à luz da ruptura do processo democrático.}

Esse problema é um fantasma no Brasil. E, no meu caso, é novamente aquela "parte de mim fora de mim constantemente a procurar-me". A reflexão sobre a República se assenta em buscar quais são as soluções que ela oferece para que eu possa pensar um Brasil democrático, mas atravessado por um conjunto de valores. Uma das dificuldades é o fato de que trocamos a República pela democracia. Não podia ser assim. Nós precisamos das duas. Uma depende da outra. 0 republicanismo fornece um repertório e uma cultura que impedem que a democracia se perca no seu princípio igualitário. Quando o Alexis de Tocqueville analisou a democracia 
norte-americana, ele disse que existia um risco de se estabelecer um despotismo democrático, no qual a democracia gera uma apatia do cidadão, que, por sua vez, abre caminhos para um regime tirânico. Já a Hannah Arendt apresentava um ponto muito forte nessa discussão, dizendo que o totalitarismo não é só uma experiência histórica e que elementos próprios dele aparecem em uma sociedade democrática. Se refletirmos ainda sobre a República de Weimar, podemos questionar: "Como foi possível aquele vigor todo terminar com Hitler no poder?" Por isso precisamos voltar a uma tradição esquecida, e a literatura e a narrativa podem abrir caminhos para explicarmos isso.

\section{Muito obrigado pela entrevista.}


